\title{
Is Scissoring a Metaphor for Disconnecting a Relationship?
}

\author{
Hosang Chu Jungyun Kang, Minhwan Lee, and Hakkyun Kim \\ School of BusinessSungkyunkwan University, Korea
}

\begin{abstract}
A great deal of attention has surrounded the role of embodied cognition in human judgments; however, it has received very little research attention, especially in the marketing field. This research is based on the idea that the act of cutting can activate perceptions of severing relationships, as well as eliciting a sense of independence. Study 1 showed that consumers are less likely to adopt a close friend's opinion when they engage in the act of cutting an object with scissors. Study 2 demonstrated that people are less likely to trust the reviews of online communities while cutting a piece of string with scissors. These lowered intentions to adopt others' opinions appeared to be mediated by increased psychological distances between the self and the information provider. In other words, people who engage in the act of scissoring unconsciously weaken or disconnect themselves from the information providers, thereby choosing not to adopt others' opinions. This research identifies the link between the physical activity of cutting and the mental disconnection concerning social relationships. The results provide implications in setting up an integrative framework of the consumer decision-making process involving embodied cognition.
\end{abstract}

\begin{abstract}
Abstrak: Begitu banyak perhatian telah dicurahkan pada kajian komponen kognisi pada sikap pengambilan keputusan oleh konsumen; namun, masih jarang ditemukan penelitian yang menghubungkan antara komponen kognisi konsumen dengan bidang pemasaran. Penelitian ini dilakukan berdasarkan adanya pendapat bahwa tindakan memutus hubungan dan tidak setia pada suatu produk akan memunculkan rasa bebas dikalangan konsumen. Studi 1 menunjukkan bahwa konsumen cenderung untuk mengadopsi pendapat teman dekat ketika mereka menentukan sikap berhenti berhubungan dengan produk tertentu, sementara studi 2 menunjukkan bahwa konsumen cenderung mempercayai pendapat komunitas online untuk pertimbangan penghentian hubungan dengan produk tertentu. Dari penelitian,ditemukan bahwa faktor yang menjadi penyebab situasi yang demikian adalah semakin jauhnya jarak antara konsumen dan produsen secara psikologis. Dengan kata lain, konsumen dapat mengambil tindakan untuk berhenti memikirkan suatu produk atau tidak setia pada produk tertentu, sehingga memilih untuk tidak mengikuti pendapat orang lain bahkan mengabaikan rekomendasi temannya. Penelitian ini membuktikan adanya hubungan fisik antara aktivitas penarikan diri dari produk tertentu dengan sikap mental pemutusan hubungan sosial. Hasil penelitian ini memberikan implikasi bahwa dalam menuntun konsumen untuk setia pada suatu produk, diperlukan pendekatan yang terintegrasi antara komunikasi pemasaran dengan pemahaman komponen kognitif konsumen.
\end{abstract}

Keywords: embodied cognition; metaphors; social distance; word-of-mouth

JEL classification: M30; M31; M39

* Corresponding author's e-mail: jungyoon13@skku.edu, and hakkyunkim@skku.edu 


\section{Introduction}

Embodied cognition is a topic of research in social and cognitive psychology, encompassing issues such as social interaction and decision-making (Borghi and Cimatti 2010). Areas of consumer research that could potentially benefit from adopting an embodied view of cognition include decision-making, information search behavior, and categorization (Malter 1996). In embodied cognition, the nature of the human mind is largely determined by the form of the human body. Philosophers, psychologists, cognitive scientists, and artificial intelligence researchers who study embodied cognition and the embodied mind argue that all aspects of cognition are shaped by aspects of the body. For example, when participants hold a pencil in their teeth, engaging the muscles used for smiling, they tend to comprehend pleasant sentences faster than unpleasant ones. On the other hand, holding a pencil between the nose and upper lip, using the muscles for frowning, has the reverse effect (Pecher and Zwaan 2005). Following developments in cognitive linguistics (Lakoff 1987; Talmy 1988), a number of studies involving embodied cognition have received a great deal of attention (Ajzen and Fishbein 1977; Cacioppo et al. 1993; Forster and Strack 1996; Goldin-Meadow et al. 2009; Labroo and Kim 2009; Labroo and Nielsen 2010; Lakoff and Johnson 1980; Lakoff and Turner 2009; Neumann and Strack 2000; Riskind and Gotay 1982; Strack et al. 1988; Thomas and Lleras 2007; Wells and Petty 1980).

Despite great attention in the academic world, little acknowledgement concerning the metaphorical effects between physical activity and cognition has been made in the marketing field. In marketing, the concept of embodied cognition has been associated with physiological factors (Rosa and Malter 2003), brand symbols in new product design (Kreuzbauer and Malter 2005), brand experiences (Gretzel et al. 2006), designing machines or artificial robots having artificial minds embedded with synthetic consciousness (Shanahan 2006), and firming one's muscles and self-regulation (Hung and Labroo 2011). By adding this conceptualization to consumer behavior, it could broaden the range of predictable consumer behavior and diminish exceptional occasional act that defies explanation by existing theories. Previous research has suggested that simulating many bodily actions resulting from or accompanying thought processes can also influence perceptions of relationships, such as familiarity, closeness, and assimilation (Barsalou 2008). These findings imply that body movements can influence the decision-making process for purchase and product evaluation. Since consumption and the decision-making process do nothappen in a vacuum, but rather in connection with other activities, consumers often decide on their buying intentions after or simultaneously with certain other activities. Following the logic of these studies on embodied cognition, this research can provide a deeper understanding of consumer behavior and greater implications to the marketing field.

This research examines how the act of scissoring influences consumer information processing and the decision-making process. In sociology and economics, the role of social networks or social ties has received much attention (DiMaggio and Louch 1998; Granovetter 1985; Ko et al. 2014; Landa 1994). In consumer research as well, research involving the influence of other people or of relationships with others on the consumer decision-making process has gradually increased (Brown and Reingen 1987; Ellisonet al. 2007; 
Frenzen and Nakamoto 1993; Twenge et al. 2001). In this research, the act of scissoring contains a figurative meaning with respect to a feeling of disconnecting relationships. Metaphors and other figurative expressions permeate ordinary discourse (Lakoff and Johnson 1980). The metaphoric process originates in neurological substrates tied to the sensory-motor-affective system (Marks 1996; Marks and Bornstein 1987), and the motor system and spatial orientation are used metaphorically to express abstract thought; thus, emotion and reason are both important in decision-making (Zaltman 1997). To examine this metaphorical effect, we operationalized the disconnection process in the following manner: string signifies a current relationship, scissors signify the process of cutting something, and the action of cutting string signifies disconnection of the relationship in this research. Based on this meaning formation process, this research focuses on the effect of the cutting action on the Word of Mouth (WOM) adoption compared to respondents in different conditions. We also examine the mediation effect of the feeling of disconnecting a relationship via a cutting action on WOM adoption. We predict that when people engage in a cutting action, they do not adopt others' opinions. We assume that people unconsciously perceive the act of scissoring or the act of cutting as a symbol of disconnecting a relationship.

The purpose of this research is to examine the influence of embodied cognition, in this case, the act of scissoring, on the decision-making process and to find this underlying psychological process by seeking a mediator. The findings can suggest meaningful implications for behavioral researchers in the consumer research field. Specifically, this research briefly reviews the literature of embodied cognition and takes a closer, deep look at the relationship between scissoring and disconnection; next, we deduce the hypotheses related to the topic; we introduce studies 1 and 2 to test the hypotheses; and finally we mention the limitations of this study and our suggestions for further research. Therefore, our findings have important implications for consumer research.

\section{Theoretical Background}

\section{Embodied Cognition}

Descartes, a philosopher of the past, believed that all human behaviors and thoughts worked separately (Descartes 1967, 1985). Similarly, the human mind was considered as the basis of all internal cognitive processes, including the acceptance of knowledge, problem-solving, and attitude formation (Ajzen and Fishbein 1977). This view has served as the dominant paradigm in consumer research, as well as in cognitive psychology. However, this belief regarding the mind-to-body relationship fails to highlight the importance of the phenomenon where organisms are embodied, as well as the relationship between the phenomenon and organisms (Cowart 2000). As a result, a new idea claiming that human thoughts, feelings, and behaviors are based on sensory experience and body condition has been proposed (Barsalou 2008; Niedenthal et al. 2005; Spellman and Schnall 2009). The process where the sensory experience and body condition produce internal human behaviors is referred to as embodied cognition. Thelen et al. (2001, p.1) define embodied cognition as the following: "Cognition depends on the kinds of experiences that come from having a body with particular perceptual and motor capacities that are inseparably linked and that together form the matrix within which 
memory, emotion, language, and all other aspects of life are meshed." That is, embodied cognition is based on the interaction between the body and the world.

Embodied cognition has been studied in various academic fields (Brooks 1999; Barsalou 1999; Grant and Spivey 1993). For instance, in the field of linguistics, embodied cognition has been actively examined regarding its close relationship with metaphors (Lakoff and Johnson 1999; Lee and Schwarz 2012; Meier et al 2012). Metaphors involve the process of describing an abstract object by using a specific concept based on cognitive experiences (Meier et al. 2012). Moreover, abstract concepts in languages are based on specific bodily cognition processes (Lakoff and Johnson 1980). For example, we characterize kind individuals as "warm-hearted" and those with the opposite disposition as "coldhearted." An experiment based on such linguistic phenomena was conducted by Williams and Bargh (2008). They found that holding a warm object, such as a cup of hot coffee or a hot therapeutic pad, could elicit affectionate behavior from individuals. The physical experience of a "warm" object is metaphorically translated into the abstract concept of a "warm" heart. An increase in the number of experimental studies similar to that of Williams and Bargh has emphasized the role of metaphors in human cognitive processes (Lee and Schwarz 2011); such research has shown that subtle and ancillary bodily experiences affect unconscious cognition (Barsalou 2008; Landau et al. 2010; Williams et al. 2009). In other words, metaphors specify abstract objects from physical experiences and influence human thoughts and decision-making processes.

There have been many studies regarding embodied cognition through the interaction between physical activities and the world
(Hung and Laboo 2011; Lee and Schwarz 2012; Schubert 2005; Well and Petty 1980; Williams and Bargh 2008; Zhong and Liljenquist 2006). For example, Hung and Labroo (2011) show that firming one's muscles can help firm willpower, and that strong willpower mediates one's ability to possess great self-control. In another example, Well and Petty (1980) suggest that overt movement can either augment or inhibit certain cognitive activities, depending on whether the movement has been positively or negatively associated with such cognitive activity in the past. One study relating the act of washing one's hands with ethical decision-making is an example of embodied cognition-focused research (Zhong and Liljenquist 2006). Zhong and Liljenquist (2006) found that immoral thoughts and behaviors tend to attract people to cleaning products. Such a discovery is based on people's innate desire to wash something off when they feel stained or dirty. Metaphorically speaking, the "stain or dirt" in this case can be interpreted as people's unethical thoughts, whereas the actions and embodied cognition stimulate people's desire to physically wash themselves; thus, the act of physically cleaning the body metaphorically reduces their moral disgust. In addition to moral boundaries, the act of washing one's hands can also affect people's decision-making processes in relation to their past positive or negative actions. According to $\mathrm{Xu}$ et al. (2012), people with positive past experiences tend to choose decisions with less risk when gambling after washing their hands, and viceversa for people with negative past experiences.

Furthermore, there are various studies based on the mechanism that physical experiences lead to psychological outcomes, including the following examples: vertical lo- 
cation representing levels of power (Schubert 2005), the odor of fish inducing suspicion (Lee and Schwarz 2012), the act of nodding in making a message more persuasive while reading it, (Wells and Petty 1980), and firming one's muscles in facilitating self-control toward a relevant goal (Hung and Labroo 2011). These studies are based on cognitive processes through bodily interactions with the outside world.

\section{Scissoring and Disconnection of Oneself from Others}

Most demonstrations of metaphorical effects on judgment and decision-making seem to occur through the process that bodily experiences activate metaphorically associated thoughts, goals and feelings (Lee and Schwarz 2010; Schnall, Benton, and Harvey 2008; Schnall et al. 2008b; Williams and Bargh 2008; Zhong and Leonardelli 2008; Zhong and Liljenquist 2006). Judgments about the literal meaning of metaphors may be affected by previously read sentences related to either the literal or figurative meaning of the metaphors' vehicles (Kemper 1989). In line with prior research, we examine the metaphorical links between physical and social distance. We normally use expressions with the word "cut," such as "cut the cord" or "cut off the relationship" to describe disconnecting a relationship. Therefore, this research gives shape to figurative meanings, such as the act of scissoring referring to disconnection; string referring to a relationship, and the action of cutting string referring to disconnecting a relationship.

Cognitive semantics that activate conceptual metaphors as the basic mechanisms of the mind (Gallese and Lakoff 2005), and embodied and metaphorical approaches can be stimulated from various sensory experiences (Lee and Schwarz 2011). In this research, we examine whether the effect of linguistic expressions involving the word "cut" can produce a metaphorical cognitive relationship through the actual act of cutting. According to previous research on embodied cognition, such metaphorical expressions can unconsciously affect our cognitive processes through the physical act of cutting an object using scissors. We investigate any possible cognitive changes in people's interpersonal attitudes resulting from the act of scissoring. To examine people's interpersonal attitudes, this research will apply Word of Mouth (WOM) to our experiments. Previous literature on WOM have usually demonstrated the effect of WOM by measuring consumers' adoption of WOM information (e.g., Fan et al. 2013; Li and Zhan 2011). Adoption refers to the persuasiveness of WOM, in that people rely on the content of WOM and make certain behavioral modifications (Cheung et al. 2008; Sussman and Siegal 2003). Thus, consumers who adopt WOM engage in purchasing decisions that depend on the recommendations of acquaintances or online reviews (Duhan et al. 1997). In this research, we examine whether the action of cutting negatively influences consumers' intentions to adopt WOM information. We also expect that the underlying mechanism of the effect of the cutting action is a feeling of disconnection from others. As a result, we propose the following hypotheses:

$H_{i}$ : The activity of scissoring has a negative impact on WOM adoption.

$\mathrm{H}_{2}$ : The impact of the activity of scissoring on WOM adoption is mediated by the feeling of disconnecting a relationship. 


\section{Study 1}

The purpose of Study 1 is to test the prediction that the cutting action has a negative influence on WOM adoption. We aim to empirically test the effect of the cutting action on an individual's intention to adopt the opinions of a close friend.

\section{Participants and Procedure}

Sixty undergraduate students (mean age $=23.01 ; 60.7 \%$ male) participated in this study in exchange for course credit. This study was a 2 (cutting action vs. control) betweensubjects design. We randomly assigned participants to one of the two conditions.

Participants were first asked to read a scenario including a WOM situation (see Appendix A). After reading the scenario, participants in the cutting action condition proceeded to a second unrelated study. They were told that the purpose of the second study was to evaluate the individual's task performance. They were asked to cut a piece of string into ten equal parts with scissors. Participants in the control condition responded to questions about their intentions to adopt a friend's opinion after reading the scenario. Participants presented their WOM adoption intention on a seven-point scale: "I rely on the friend's opinion," and, "I think the friend's opinion is professional." Responses to these two items were combined into a WOM adoption intention measure $(\alpha=0.60)$.

\section{Results and Discussion}

Most experimental consumer studies have checked whether a manipulation is suc- cessful in confirming that a treatment can create an intended mindset. However, this process cannot be applied to research on embodied cognition. According to previous literature, the effects of bodily experiences are maximized when they are subtle and do not attract attention (Lee and Schwarz in press; Reinhard et al. 2012). Schwarz (2012) suggests "feeling-as-information theory," in that the effects of subjective experiences -including moods, emotions, metacognitive experiences, and bodily sensations- can be eliminated once recognized. Therefore, we excluded the manipulation checks for our experimental conditions in order to maintain the metaphorical effects of bodily experiences. To mitigate the confounding effect from other variables, the homogeneity for testing the equality of error variance was conducted. The results of a Levene's test showed that equal variances are assumed ( $p>0.05)$, which fulfilled the requirement of the analysis of variance.

An analysis of variance (ANOVA), with WOM adoption intention as the dependent variable and cutting action conditions as the independent variable, showed a significant effect. Participants in the cutting action condition presented lower WOM adoption intention than those in the control condition $\left(M_{\text {cut }}=3.32, S D_{\text {cut }}=1.18\right.$ vs. $M_{\text {control }}=3.84$, $S D_{\text {control }}=0.80 ; F(1,60)=4.06, p<0.05$; see Figure 1). The cutting action significantly weakened people's intention to adopt a friend's opinions. Thus, hypothesis 1 was supported. ${ }^{1}$

\footnotetext{
${ }^{1}$ We examined whether participants who engaged in the cutting action would place a premium on being alone, even when choosing activities that could be enjoyed with friends and family. We presented a six-item questionnaire that asked participants to indicate their preferences (e.g., "I prefer to work on a project with a peer than alone"). Participants in the cutting action condition were more likely to prefer individually focused activities than those in the control condition $\left(\mathrm{M}_{\text {cut }}=3.73, \mathrm{SD}=0.92 \mathrm{vs} . \mathrm{M}_{\text {control }}=4.27, \mathrm{SD}=0.70 ; \mathrm{F}(1,60)=6.64, \mathrm{p}<.05\right)$. These results showed that cutting action could undermine a sense of connection.
} 
Figure 1 (Study 1). The Influence of the Cutting Action on WOM Adoption Intention

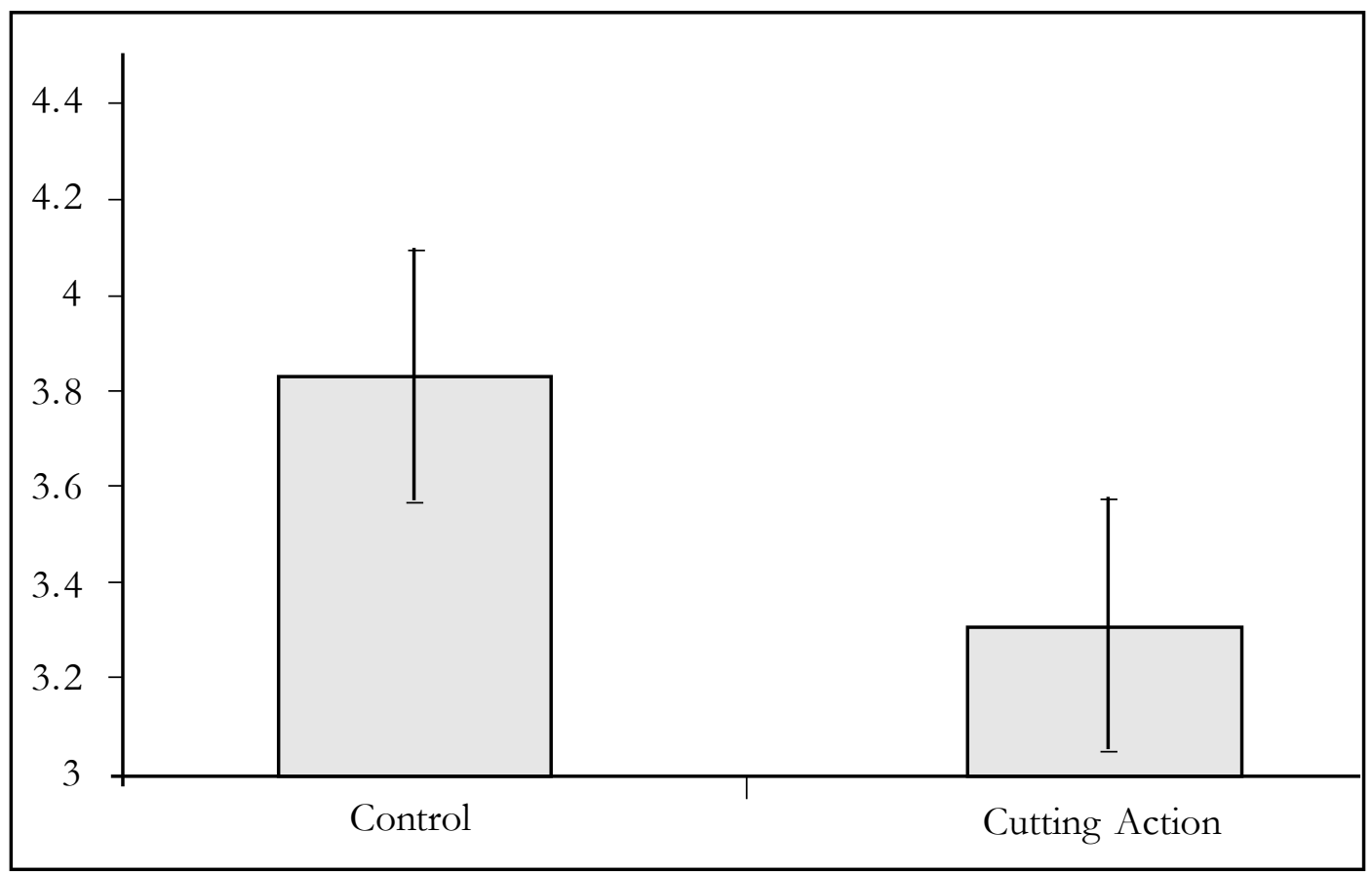

The results from Study 1 provide empirical evidence for our hypotheses. When people cut something with scissors, they do not rely on a friend's opinion, even if he or she is a very close friend.

\section{Study 2}

The purpose of Study 2 was twofold. First, we intended to replicate the findings of Study 1 with a different type of product in a different context. In this study, we chose a hotel's standard of service as the target of evaluation, since hotel selection is a product category in which consumers actively seek others' opinions in online communities. Also, unlike in Study 2, this study will replicate the effect of embodied cognition for a product whose benefits are primarily hedonic. Thus, these changes made to Study 2 will enhance both the ecological and external validity of the findings. Second, we aimed to examine the underlying mechanism with which the act of cutting pieces of string with scissors influences consumers' intentions to adopt word of mouth information. By noting the metaphoric meaning found in the cutting action, we investigated the role of experiencing a feeling of disconnection of oneself from others.

\section{Participants and Procedure}

Forty underg raduate students (mean age $=23.90 ; 37.5 \%$ male) participated in this study in exchange for $\$ 8$. This study was a 2 (cutting action vs. control) between-subjects design. We randomly assigned participants to one of the two conditions.

The procedure was identical to that of Study 1. Participants were first asked to read a scenario, including the WOM situation (see Appendix B). Unlike Study 1, the scenario of Study 2 included a situation with an online community WOM. Participants presented their WOM adoption intention on a seven- 
point scale: "I agree with the reviewer," "I will accept the information provided by the reviewer," "The information provided by the reviewer is helpful in evaluating the hotel," and, "I will adopt the comments of the reviewer." Responses to these four items were combined into a WOM adoption intention measure $(\alpha=0.91)$. Then, participants were asked to answer questions about their feeling of connection (Wasko and Faraj 2005): "I feel emotional intimacy toward this online community," and, "I feel proud as a member of this online community." Responses to these two items were combined into a measure of the ties felt towards the online community $(\alpha=0.91)$.

\section{Results and Discussion}

From the results of the homogeneity test, the error variance of the dependent variable was equal across the groups, which was sufficient for analyzing the analysis of variance ( $p>0.05)$. An ANOVA run on WOM adoption intention revealed a significant effect. Participants in the cutting action condition presented lower WOM adoption intentions than those in the control condition $\left(\mathrm{M}_{\text {cut }}=5.11, \mathrm{SD}_{\text {cut }}=1.13\right.$ vs. $\mathrm{M}_{\text {control }}=5.81$, $\mathrm{SD}_{\text {control }}=0.84 ; \mathrm{F}(1,40)=4.62, \mathrm{p}<0.05$; see Figure 2). Thus, the action significantly weakened people's intention to adopt a reviewer's opinions.

To determine whether a feeling of connection mediated the impact of the cutting action on WOM adoption intention or not, we conducted a mediation analysis. We used the bootstrapping method with bias-corrected confidence estimates (Preacher and Hayes 2004). Analyses and bootstrap estimates (based on 5,000 bootstrap samples) indicated that the total effect $(\alpha=0.70, t=2.15, \mathrm{p}<$ $0.05)$ of the cutting action condition was not significant $(\alpha=0.26, \mathrm{t}=1.12, \mathrm{p}>0.26)$ when the sense of connection index was included in the model. Furthermore, the indirect effect through a feeling of connection was sig-

Figure 2 (Study 2). The Influence of the Cutting Action on WOM Adoption Intention

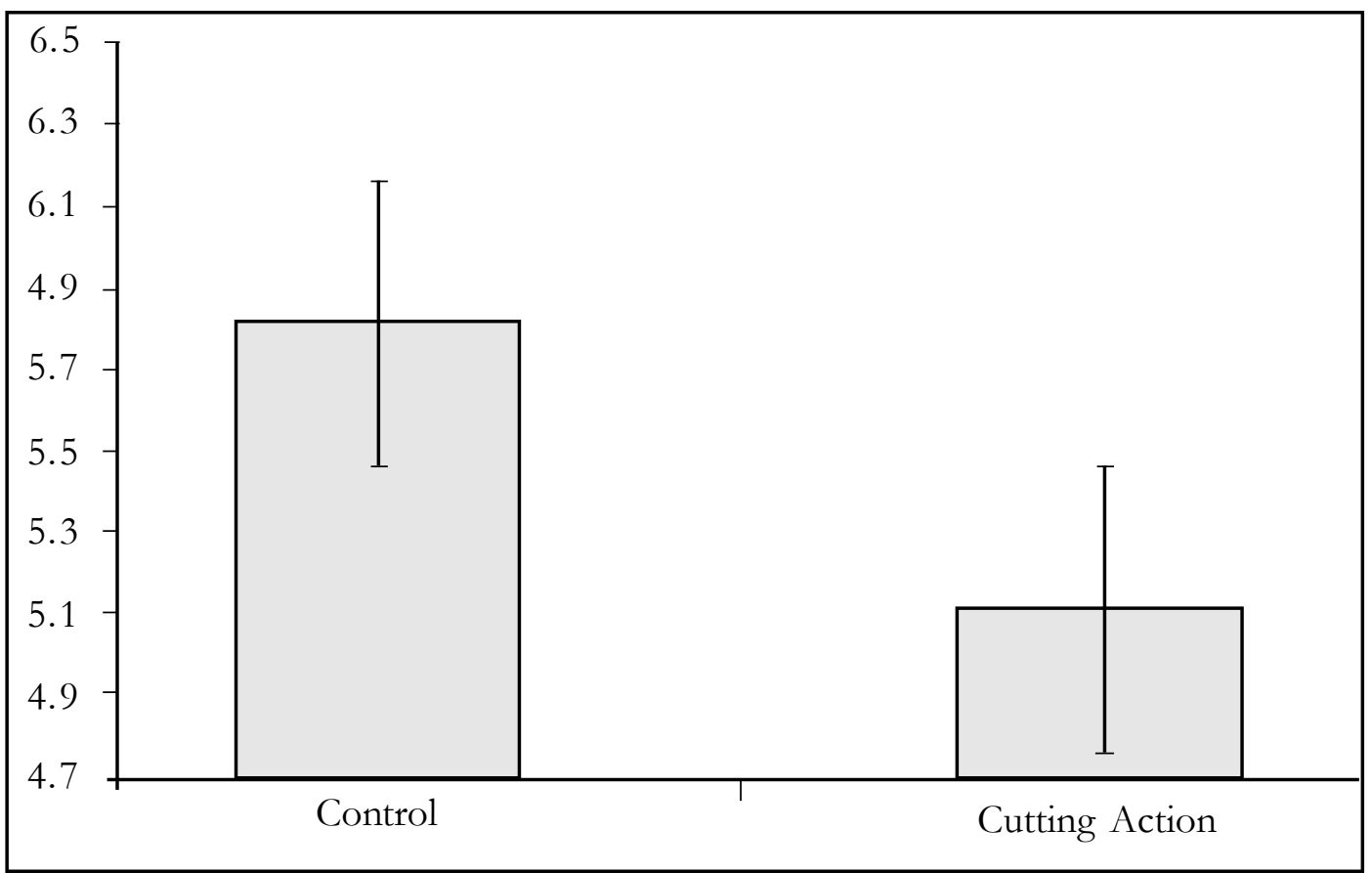


Figure 3 (Study 2). Mediating Role of a Feeling of Disconnection of Oneself From an Online Community on WOM Adoption Intention

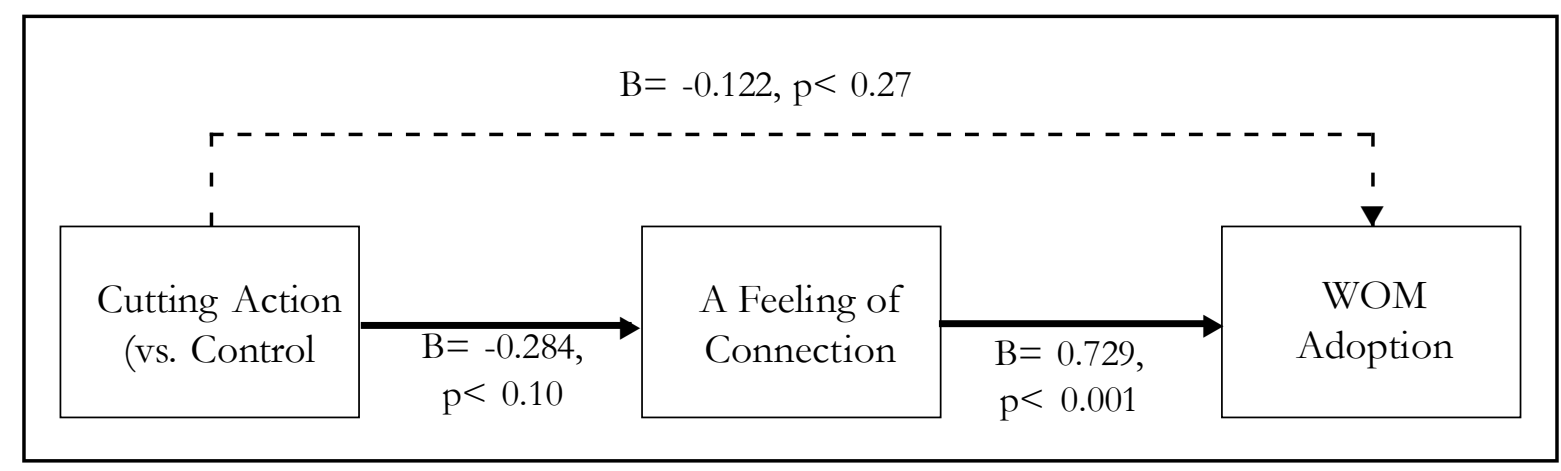

nificant, with a 95 percent confidence interval of 0.0076 to 1.0610 . These results suggest that a feeling of disconnecting oneself from the online community mediated the effect of the cutting action on WOM adoption (see Figure 3). In other words, the cutting action led to a weakened sense of connection for an affiliated group; then, disconnection of a relationship induced the tendency not to accept others' opinions. Thus, hypothesis 2 was supported. ${ }^{2}$

\section{General Discussion}

We investigated the influence of a cutting action on WOM adoption. When people engage in a cutting action, they tend not to accept the opinions of others, compared to those who do not engage in such actions. Study 1 showed that participants in the cutting action condition did not accept their friends' opinions, even if they were very close friends, compared to those in the control condition. Study 2 showed that participants in the cutting action condition did not depend on the review of an online community member, compared to those in the control condition. Further, Study 2 demonstrated that the influence of a cutting action on WOM adoption intention was mediated by a feeling of disconnecting a relationship. In other words, the cutting action weakened a feeling of connection and undermined it, thus influencing WOM adoption.

This research makes an important contribution to the embodied cognition literature. Broadly speaking, the current research demonstrates that embodied cognition can play a role in decision-making, such as WOM adoption. In particular, scissoring was found to activate thoughts about disconnecting relationships; moreover; it was found to weaken

\footnotetext{
${ }^{2}$ We ran a mediation analysis following the work of Baron and Kenny (1986). We found that the condition of the cutting action significantly influenced WOM adoption intentions $(b=-0.33, t=-2.15, p<.05)$. The negative coefficient showed that the cutting action had a negative effect on WOM adoption intentions, since the cutting action condition was coded as 1 , and the control condition was coded as 0 . The condition of the cutting action also marginally predicted a feeling of connection $(b=-0.28, t=-1.83, p<.10)$. Finally, when both the condition of the cutting action and a feeling of connection were included in the model, a feeling of connection significantly predicted WOM adoption intention $(b=0.73, t=6.70, p<0.001)$, whereas the effect of the condition of the cutting action became insignificant $(b=$ $-0.12, \mathrm{t}=-1.12, \mathrm{p}>0.27$; see Figure 3). Thus, a feeling of connection was found to fully mediate the relationship between the condition of the cutting action and WOM adoption intention.
} 
a feeling of connection, thereby influencing the degree to which consumers rely on others' opinions or suggestions. This phenomenon is consistent with research in embodied cognition, showing that incidental bodily experiences may activate metaphorically associated thoughts, goals, and feelings (e.g., Lee and Schwarz 2011).

Our research also contributes to prior research on WOM adoption. Recent research on WOM adoption sheds light on the moderating or conditional factors affecting WOM adoption, such as the characteristics of the information, source and receiver. Chang and Wu (2014) suggest that the interaction among the persuasiveness of the information, source credibility, and recipients' commitment directly influences actual WOM adoption, verifying that perceived WOM credibility positively influences the receivers' adoption of WOM (Fan et al. 2013). Further, negative WOM is more dependent on the strength of WOM and interpersonal factors than positive WOM (Sweeny et al. 2014). In the travel context, Filieri and McLeay (2013) show that information timeliness, accuracy, relevancy and value addition significantly predict online review adoption. In this regard, our research reinforces how WOM adoption is facilitated or inhibited by incorporating subtle bodily experiences into the WOM literature.

In addition to the theoretical value, our findings possess practical applicability in the marketing domain. Nowadays consumers are exposed to various types of marketing information in their daily lives, and such exposure tends to occur while consumers perform certain gestures or actions. For instance, some may listen to the radio or watch TV while preparing food in the kitchen, or consumers may read magazines or newspapers while performing common tasks, such as eating at the table or clipping their fingernails. Given the various occasions where consumers are performing certain actions and making purchase decisions, or making sense of marketing stimuli, the current research suggests that consumer information processing and judgments could be altered by the actions or tasks in which the consumers are simultaneously engaged. Therefore, marketers can gauge how their information is understood or how their products are viewed by considering the possible actions consumers tend to take while being exposed to specific information or products. In other words, considering the possibility of multitasking consumers can enhance the efficacy of marketing communications. Also, our research cautions marketers not to embed scissoring metaphorical symbols or images into their media messages, as they could lower the effect of WOM diffusion.

In addition, we believe that the present work holds important implications for consumers' welfare and well-being. Previous research was focused on the strength of the ties between the WOM sender and the receiver as the interpersonal factor in WOM influence. According to Vazquez-Casielles et al. (2013), the stronger the tie is between the sender and the receiver, the more the receiver will adopt the WOM contents. Alexandrov, Lilly, and Babakus (2013) also pay attention to the social bonding role of WOM that accomplishes social needs. That is, people have the tendency to share WOM with the goal of social interaction. Our research, however, suggests that the activity of scissoring arouses a feeling of disconnecting a relationship, and thus decreases WOM adoption. Drawing upon the role of feelings related to disconnecting a relationship, our results can extend the decision-making context with the influence of personal relationships. That is, various sensory experience management, at the point of purchase involving a scissoring action can 
influence purchase behavior. Applied to the retail context, these findings indicate that consumers who engaged in cutting might successfully resist a salesperson's flattery or insincere compliments. Therefore, it would be worthwhile for customers to make their own decisions wisely. Furthermore, a typical sales tactic is to develop intimacy or to reduce psychological distance, as in the case of mimicry or finding communalities (such as the same hometown, accents, or favorite sports teams), and consumers tend to be pressured into buying unwanted items. Our research shows that such pressure would be attenuated by scissoring or cutting actions because the scissoring action can successfully decrease a feeling of connection and may help activate the goal as rational consumption.

Our research has some limitations that can be addressed by future research. In these days, social network services, such as Facebook, Twitter, and Instagram, play an important role in establishing and maintaining social relationships. Future research will be encouraged to consider these SNS contexts. We expect that people who are exposed to SNS relationships will be more likely to adopt WOM contents because they realize the importance of relationships. In contrast, the effects of WOM, online reviews, or advertisements, including other consumers' opinions, will be diminished for people who have just blocked SNS friends or for those who have just inactivated their SNS accounts. Considering that WOM marketing is becoming more important with heavy SNS users through the development of electronic devices such as smartphones or tablet PCs, it would be very valuable to investigate the influences of unintended bodily experiences on such WOM adoption. Second, in this research, we considered only negative WOM situations. Future research could also examine the influence of a cutting action on adoption intentions for positive WOM or others' recommendations. Third, future research could examine whether the cutting action influences not only a feeling of connection, but also disconnection in other domains. Previous research has shown that physical cleansing can remove the residue of past experiences (Zhong and Liljenquist 2006; Xu et al. 2012; Kaspar 2013). These studies suggest that the act of cleaning allows people to metaphorically obliterate the "stains" of past recollections (Lee and Schwarz 2011). We expect that the cutting action could block the influences of past memories on the present, as well. Lastly, future research could employ interdisciplinary approaches. These approaches integrating psychology, linguistics, cognitive science, and neurobiology can provide new opportunities for the embodied cognition field. Especially, meaningful findings of embodied cognition, including observations about consumer behavior and connections with cognition, could encourage human-computer interaction development, which could establish an abundant ecosystem by changing the user experience.

\section{Conclusion}

Building on the literature on embodied cognition, we suggest that physical movements can significantly influence consumers' decision making and information processing. Two experiments find that the act of scissoring tends to lower word-of-mouth adoption by decreasing a feeling of connection, identifying the link between the physical activity of cutting and mental disconnection concerning social relationships. This research has implications for referral programs, word-ofmouth communication and social networking services. 
Chu et al.

\section{Acknowledgment}

This research was supported by a National Research Foundation of Korea Grant, funded by the Korean government (NRF-2013S1A5A2A03045216).

\section{References}

Ajzen, I., and M. Fishbein. 1977. Attitude-behavior relations: A theoretical analysis and review of empirical research. Psychological Bulletin 84 (5): 888-918.

Alexandrov, A., B. Lilly, and E. Babakus. 2013. The effects of social- and self-motives on the intentions to share positive and negative word of mouth. Journal of the Academy of Marketing Science 41 (5): 531 546.

Baron, R. M., and D. A. Kenny. 1986. The moderator-mediator variable distinction in social psychological research: Conceptual, strategic, and statistical considerations Journal of personality and social psychology 51 (6): 1173-1182.

Barsalou, L. W. 1999. Perceptual symbol systems. Behavioral and Brain Sciences 22 (4): 637-660.

Barsalou, L. W. 2008. Grounded cognition. Annual Review of Psychology 59 (1): 617-645.

Borghi, A. M., and F. Cimatti. 2010. Embodied cognition and beyond: Acting and sensing the body. Neuropsychologia 48 (3): 763-773.

Brooks, R. 1999. Cambrian Intelligence.Cambridge, MA: MIT Press.

Brown, J. J., and P. H. Reingen. 1987. Social ties and word-of-mouth referral behavior. Journal of Consumer Research 14 (3): 350-362.

Cacioppo, J. T., J. R. Priester, and G. G. Berntson. 1993. Rudimentary determinants of attitudes: Arm flexion and extension have differential effects on attitudes. Journal of Personality and Social Psychology 65 (1): 5-17.

Chang, H. H., and L. H. Wu. 2014. An examination of negative E-WOM adoption: Brand commitment as a moderator. Decision Support Systems 59 (March): 206-218.

Cheung, C. M. K., M. K. O. Lee, and N. Rabjohn. 2008. The impact of electronic word-of-mouth: The adoption of online opinions in online customer communities. Internet Research 18 (3): 229-247.

Cowart, M. R. 2000. A theoretical framework for evaluating embodied cognition. Ph.D. Dissertation. University of Wisconsin, Madison.

Descartes, R. 1967. Meditations on first philosophy (1641). The Philosophical Writings of Descartes 2. Cambridge University Press.

Descartes, R. 1985. The Philosophical Writings of Descartes, Cambridge University Press.

Duhan, D. F., S. D. Johnson, J. B. Wilcox, and G. D. Harrell. 1997. Influences on consumer use of wordof-mouth recommendation sources. Journal of the Academy of Marketing Science 25 (4): 283-295.

DiMaggio, P., and H. Louch. 1998. Socially embedded consumer transactions: For what kinds of purchases do people most often use networks? American Sociological review 63: 619-637.

Ellison, N. B., C. Steinfield, and C. Lampe. 2007. The benefits of facebook "friends:" Social capital and college students' use of online social network sites. Journal of Computer Mediated Communication 12 (4): 1143-1168. 
Fan, Y., Y. Miao, Y. Fang, and R. Lin. 2013. Establishing the adoption of electronic word-of-mouth through consumers' perceived credibility. International Business Research 6 (3): 58-65.

Filieri, R., and F. McLeay. 2013. E-WOM and accommodation: An analysis of the factors that influence travelers' adoption of information from online reviews. Journal of Travel Research 53 (1): 44-57.

Förster, J., and F. Strack. 1996. Influence of overt head movements on memory for valenced words: A case of conceptual-motor compatibility. Journal of Personality and Social Psychology 71 (3): 421-430.

Frenzen, J. K., and K. Nakamoto. 1993. Structure, cooperation, and the flow of market-information. Journal of Consumer Research 20 (3): 360-375.

Gallese, V., and G. Lakoff. 2005. The brain's concepts: The role of the sensory-motor system in conceptual knowledge. Cognitive Neuropsychology 22 (3-4): 455-479.

Gildea, P., and S. Glucksberg. 1983. On understanding metaphor: The role of context. Journal of Verbal Learning and Verbal Behavior 22 (5): 577-590.

Goldin-Meadow, S., S. W. Cook, and Z. A. Mitchell. 2009. Gesturing gives children new ideas about math. Psychological Science 20 (3): 267-272.

Granovetter, M. 1985. Economic action and social structure: The problem of embeddedness. American Sociological Review 91: 481-501.

Grant, E. R., and M. J. Spivey. 2003. Eye movements and problem solving: Guiding attention guides thought. Psychological Science 14 (5):462-466.

Gretzel, U., D. R. Fesenmaier, and J. T. O'Leary 2006. The transformation of consumer behaviour. Tourism Business Frontiers: 9-18.

Hung, I. W., and A. A. Labroo. 2011. From firm muscles to firm willpower: Understanding the role of embodied cognition in self-regulation. Journal of Consumer Research 37 (0): 1046-1064.

Kaspar, K. 2013. Washing one's hands after failure enhances optimism but hampers future performance. Social Psychological and Personality Science 4 (1): 69-73.

Kemper, S. 1989. Priming the comprehension of metaphors. Metaphor and Symbol 4 (1): 1-17.

Ko, H., C. Chung, and M. Park. 2014. What determines strength of ties? Organizational cultures as key antecedents. Journal of Marketing Thought 1 (1): 67-76.

Kreuzbauer, R., and A. J. Malter. 2005. Embodied cognition and new product design: Changing product form to influence brand categorization. Journal of Product Innovation Management 22 (2): 165-176.

Labroo, A. A., and S. Kim. 2009. The instrumentality heuristic why metacognitive difficulty is desirable during goal pursuit. Psychological Science 20 (1): 127-134.

Labroo, A. A., and J. H. Nielsen. 2010. Half the thrill is in the chase: Twisted inferences from embodied cognitions and brand evaluation. Journal of Consumer Research 37 (1): 143-158.

Lakoff, G. 1987. Women, Fire and Dangerous Things: What Categories Reveal About the Mind. Chicago: University of Chicago Press.

Lakoff, G., and M. Johnson. 1980. Conceptual metaphor in everyday language. The Journal of Philosophy 77 (8): 453-486.

Lakoff, G., and M. Johnson. 1999. Philosophy in the Flesh: The Embodied Mind and Its Challenge to Western Thought. New York: Basic Books.

Lakoff, G., and M. Turner. 2009. More than CoolReason: A Field Guide to Poetic Metaphor. Chicago: University of Chicago Press. 
Landa, J. T. 1994. Trust, Ethnicity, and Identity: Beyond the New Institutional Economics of Ethnic Trading Networks, Contract Law, and Gift Exchange. MI: University of Michigan Press.

Landau, M. J., B. P. Meier, and L. A. Keefer. 2010. A metaphor-enriched social cognition. Psychological Bulletin 136 (6): 1045-1067.

Lee, S. W., and N. Schwarz. 2010. Dirty hands and dirty mouths: Embodiment of the moral purity metaphor is specific to the motor modality involved in moral transgression. Psychological Science 21: $1423-1425$.

Lee, S. W., and N. Schwarz. 2011. Wiping the slate clean: Psychological consequences of physical cleansing. Current Directions in Psychological Science 20 (5): 307-311.

Lee, S. W., and N. Schwarz. 2012. Bidirectionality, mediation, and moderation of metaphorical effects: The embodiment of social suspicion and fishy smells. Journal of Personality and Social Psychology 103 (5):737-749.

Lee, S. W., and N. Schwarz (in press). Metaphor in judgment and decision making. In Landau, M. J., M. D. Robinson, and B. P. Meier (Eds.) Metaphorical Thought in Social Life. Washington, DC: American Psychological Association.

Li, J., and L. J. Zhan. 2011. Online persuasion: How the written word drives WOM evidence from consumer-generated product reviews. Journal of Advertising Research 51 (1): 239-257.

Malter, A. J. 1996. An introduction to embodied cognition: Implications for consumer research. Advances in Consumer Research 23 (1): 272-276.

Marks, L. E. 1996. On perceptual metaphors. Metaphor and Symbolic Activity 11 (1): 39-66.

Marks, L. E., and M. H. Bornstein. 1987. Sensory similarities: Classes, characteristics, and cognitive consequences. Cognition and Symbolic Structures. The Psychology of Metaphorical Transformations. 49-65. Norwood, NJ: Ablex.

Meier, B. P., S. K. Moeller, M. Riemer-Peltz, and M. D. Robinson. 2012. Sweet taste preferences and experiences predict prosocial inferences, personalities, and behaviors. Journal of Personality and Social Psychology 102 (1): 163-174.

Meier, B. P., S. Schnall, N. Schwarz, and J. A. Bargh. 2012. Embodiment in social psychology. Topics in Cognitive Science 4 (4): 705-716.

Neil, D. T., and T. L. Chartrand. 2011. Embodied emotion perception: Amplifying and dampening facial feedback modulates emotion perception accuracy. Social Psychological and Personality Science 2 (6): 673678.

Neumann, R., and F. Strack. 2000. Approach and avoidance: The influence of proprioceptive and exteroceptive cues on encoding of affective information. Journal of Personality and Social Psychology 79 (1): 39-48.

Niedenthal, P. M., L. W. Barsalou, P. Winkielman, S. Krauth-Gruber, and F. Ric. 2005. Embodiment in attitudes, social perception, and emotion. Personality and Social Psychology Review 9 (3): 184-211.

Pecher, D., and R. A. Zwaan. 2005. Grounding Cognition: The Role of Perception and Action in Memory, Language, and Thinking. Cambridge University Press.

Preacher, K. J., and F. H. Andrew. 2004. SPSS and SAS procedures for estimating indirect effects in simple mediation models. Behavior Research Methods, Instruments, and Computers 36 (4): 717-731. 
Reinhard, D., J. Chandeler, and N. Schwarz. 2012. Knowing what's inside counts: Prime awareness diminishes effects of embodied metaphors. Hot Topic Talk at the Embodiment Preconference of the Society for Personality and Social Psychology. San Diego, CA.

Riskind, J. H., and Gotay, C. C. 1982. Physical posture: Could it have regulatory or feedback effects on motivation and emotion? Motivation and Emotion 6 (3): 273-298.

Rosa, J. A., and A. J. Malter. 2003. E-(Embodied) knowledge and e-commerce: How physiological factors affect online sales of experiential products. Journal of Consumer Psychology 13 (1): 63-73.

Schnall, S., J. Benton, and S. Harvey. 2008. With a clean conscience cleanliness reduces the severity of moral judgments. Psychological Science 19 (12): 1219-1222.

Schnall, S., K. D. Harber, J. K. Stefanucci, and D. R. Proffitt. 2008. Social support and the perception of geographical slant. Journal of Experimental Social Psychology 44 (5): 1246-1255.

Schubert, T. W. 2005. Your highness: Vertical positions as perceptual symbols of power. Journal of Personality and Social Psychology 89 (1): 1-21.

Schwarz, N. 2012. Feeling-as-information theory. In Van Lange, P. A. M., A. W. Kruglanski, and E. T. Higgins (Eds.). Handbook of Theories of Social Psychology: 289-308. Thousand Oaks, CA: Sage.

Schwarz, N., W. Servay, and M. Kumpf. 1985. Attribution of arousal as a mediator of the effectiveness of fear-arousing communications. Journal of Applied Social Psychology 15 (2): 178-188.

Shanahan, M. 2006. A cognitive architecture that combines internal simulation with a global workspace. Consciousness and Cognition 15(2): 433-449.

Spellman, B. A., and S. Schnall. 2009. Embodied rationality. Queen's Law Review 35: 117-164.

Strack, F., L. L. Martin, and S. Stepper. 1988. Inhibiting and facilitating conditions of the human smile: A nonobtrusive test of the facial feedback hypothesis. Journal of Personality and Social Psychology 54 (5): 768-777.

Sussman, S. W., and W. S. Siegal. 2003. Informational influence in organizations: An integrated approach to knowledge adoption. Information Systems Research 14 (1): 47-65.

Sweeney, J., G. Soutar, and T. Mazzarol. 2014. Factors enhancing word-of-mouth influence: Positive and negative service-related messages. European Journal of Marketing 48 (1/2): 336-359.

Talmy, L. 1988. Force dynamics in language and cognition. Cognitive Science 12 (1): 49-100.

Thelen, E., G. Schoner, C. Scheier, and L.B. Smith. 2001. The dynamics of embodiment A field theory of infant preservative reaching. Behavioral and Brain Sciences 24 (1): 1-34.

Thomas, L. E., and A. Lleras. 2007. Moving eyes and moving thought: On the spatial compatibility between eye movements and cognition. Psychonomic Bulletin and Review 14 (4): 663-668.

Twenge, J. M., R. F. Baumeister, C. N. DeWall, N. J. Ciarocco, and J. M. Bartels. 2007. Social exclusion decreases prosocial behavior. Journal of Personality and Social Psychology 92 (1): 55-56.

Vázquez-Casielles, R., A. Suárez-Álvare, and A. Del Río-Lanza. 2013. The word of mouth dynamic: How positive (and negative) WOM drives purchase probability. Journal of Advertising Research 53 (1): 43-60.

Wasko, M. M., and S. Faraj. 2005. Why should I share? Examining social capital and knowledge contribution in electronic networks of practice. MIS Quarterly 29 (1): 35-57.

Wells, G. L., and R. E. Petty. 1980. The effects of over head movements on persuasion: Compatibility and incompatibility of responses. Basic and Applied Social Psychology 1 (3): 219-230. 
Williams, L. E., and J. A. Bargh. 2008. Experiencing physical warmth promotes interpersonal warmth. Science 322 (5901): 606-607.

Williams, L. E., J. H. Huang, and J. A. Bargh. 2009. The scaffolded mind: Higher mental processes are grounded in early experience of the physical world. European Journal of Social Psychology 39 (7): 12571267.

Wilson, M. 2002. Six views of embodied cognition. Psychonomic Bulletin and Review 9 (4): 625-636.

Xu, A. J., R. Zwick, and N. Schwarz. 2012. Washing away your (good or bad) luck: Physical cleansing affects risk-taking behavior. Journal of Experimental Psychology 141 (1): 26-30.

Zaltman, G. 1997. Rethinking market research: Putting people back in. Journal of Marketing Research 34 (4): 424-437.

Zhong, C. B., and G. J. Leonardelli. 2008. Cold and lonely does social exclusion literally feel cold?. Psychological Science 19 (9): 838-842.

Zhong, C. B., and K. Liljenquist. 2006. Washing away your sins: Threatened morality and physical cleansing. Science 313 (5792): 1451-1452. 


\section{Appendix A. The scenario for Study 1}

On a nice sunny afternoon, I met my friend "A" in the lobby after class. We graduated from the same high school, and still live in the same neighborhood. Because we have similar personalities and tastes, we have maintained a good relationship since childhood. We are currently attending the same university and are in the same club activities.

I : "My laptop is broken. Maybe it's time to get a new one. Can you recommend a good laptop for me?

A : "I heard that Ultra-book from brand 000 is good, so I bought the laptop. But, the Ultrabook is heavier than I thought and the loading speed is so slow."

\section{Appendix B. The scenario for Study 2}

Reviewer: "Last summer, I stayed at 00 hotel when I went to Cebu. First of all, transportation from the Cebu airport to the hotel was too complex. When I arrived at the hotel, I found that the location of the hotel is too far from the sea, and there were no shopping centers around the hotel. Given 00 is a four-star hotel, it is dirtier and smaller than what I had expected. Because there were not any amenities, it was uncomfortable staying in the hotel. I do not recommend the hotel to members of this community. 
